\title{
Hydrodynamics of a reactor with updated structure of frame mixing device
}

\author{
V.O. Zazymko ${ }^{1}$ (0000-0002-7343-3187), M.F. Kalinina ${ }^{1}$ (0000-0003-0455-138X), \\ V.Y. Shibetsky ${ }^{1}$ (0000-0001-5482-0838), O.M. Nedbailo ${ }^{1,2}$ (0000-0003-1416-9651)
}

${ }^{1}$ - National Technical University of Ukraine "Igor Sikorsky Kyiv Polytechnic Institute", av. Peremogy, Bldg. 37, Kyiv, 03056, Ukraine

Tel.: +380979447044

E-mail:vitalikzazymko@gmail.com,Kalinina.kpi@gmail.com,sjavva@mail.ru

${ }^{2}$ - Institute of Engineering Thermophysics of NAS of Ukraine, str. Bulakhovskogo, 2, Bldg. 2, Kyiv, 03164, Ukraine

Tel.: +380444242527

E-mail:nan_sashulya@ukr.net

Article info: received 01.09.2021, revised 03.09.2021, accepted 17.09.2021

Zazymko, V.O., Kalinina, M.F., Shibetsky, V.Y., Nedbailo, O.M. (2021) Hydrodynamics of a reactor with updated structure of frame mixing device, 3(52), DOI: 10.26909/csl.3.2021.1

This article is devoted to computer simulation of the hydrodynamic situation in a reactor with a standard design and an upgraded design of a frame stirrer. A comparative analysis of the hydrodynamics of fluid flows occurring in the volume due to the use of classical and modernized design was performed. An upgraded design of a frame stirrer for homogenizing the medium in a reactor has been proposed.

The aim of this work was to study the influence of the geometry of the stirrer blades and their location in space on the speed and direction of flows in the reactor.

The basis for the new design of the mixing device was the standard design of the frame mixer with two horizontal jumpers. Installation of additional blades and their placement at a certain angle to the vertical and horizontal planes and relative to each other was considered as one of the methods of improving the design.

For this work, the study was conducted in the universal software system of finite element analysis ANSYS. Computer simulation is used to analyze complex systems and processes based on a computer model.

The simulation was performed to analyze the influence of the geometry of the mixing device on the speed and direction of fluid flow in the apparatus. To conduct the study, 3D-models of two different types of geometry of the mixing device were built, physicomechanical parameters of the environment in the reactor were set and on the basis of these data the mixing process in the apparatus was modeled. In this work, the influence of plate geometry and their location in space on hydrodynamics is investigated. The basis of the proposed design of the mixing device is the task of intensifying the mixing process by increasing the mixing efficiency along the height of the apparatus.

A comparative analysis of the direction of fluid flow, its velocity and temperature change using a standard and upgraded design of the mixing device was performed.

It was found that when installing additional plates that are located at an angle to the horizontal and vertical planes in the reactor there are additional axial and radial fluid flows, which improves homogeneity and increases the intensity of mixing.

Key words: mixing device, hydrodynamics, homogenization, intensity, reactor.

\section{Гідродинаміка реактора з модернізованою конструкцією рамного перемішуючого пристрою}

\author{
В.О. Зазимко ${ }^{1}$ М.Ф. Калініна ${ }^{1}$, В.Ю. Шибецький ${ }^{1}$, О.М. Недбайло ${ }^{1,2}$ \\ 1 - Національний технічний університет Украӥни "Київський політехнічний інститут \\ імені Ігоря Сікорського”, Київ, Україна \\ 2 - Інститут технічної теплофізики НАН України, Київ, Україна
}


Стаття присвячена комп'ютерному моделюванню гідродинамічної обстановки в реакторі зі стандартною конструкцією і модернізованою конструкцією рамного перемішуючого пристрою.

Був проведений порівняльний аналіз гідродинаміки потоків рідини, що виникають в об'ємі за рахунок використання класичної та модернізованої конструкції. Було запропоновано модернізовану конструкцію рамного перемішуючого пристрою для гомогенізації середовища в реакторі.

Метою даної роботи було дослідження впливу геометрії лопатей перемішуючого пристрою та їх розташування у просторі на швидкість та напрями потоків у реакторі.

Основою для нової конструкції перемішуючого пристрою слугувала стандартна конструкція рамної мішалки з двома горизонтальними перемичками. Встановлення додаткових лопатей і розташування їх під певним кутом до вертикальної та горизонтальної площин та одна відносно одній розглядалось як один із методів удосконалення конструкції.

Для даної роботи дослідження були проведені в універсальній програмній системі кінцево-елементного аналізу ANSYS. Комп’ютерне моделювання використовується для аналізу складних систем та процесів на основі комп'ютерної моделі.

Моделювання проведено з метою аналізу впливу геометрії перемішуючого пристрою на швидкість і напрям потоків рідини в апараті. Для проведення дослідження були побудовані 3D-моделі двох різних типів геометрії перемішуючого пристрою, були задані фізико-механічні параметри середовища в реакторі та на основі цих даних був змодельований процес перемішування в апараті.

В даній роботі досліджений влив геометрії пластин та їх розташування у просторі на гідродинаміку. В основу запропонованої конструкції перемішуючого пристрою поставлена задача інтенсифікації процесу перемішування за рахунок підвищення ефективності перемішування по висоті апарата.

Був проведений порівняльний аналіз параметрів потоків рідини: швидкості та зміни температури при використанні стандартної та модернізованої конструкцій перемішуючого пристрою.

Виявлено, що при встановленні додаткових пластин, що розташовані під кутом до горизонтальної та вертикальної площин в реакторі виникають додаткові осьові та радіальні потоки рідини. Такі технічні особливості покращують гомогенність та збільшують інтенсивність перемішування.

\section{Вступ}

Основною метою таких галузей промисловості як біотехнологічна, хімічна та харчова є підвищення якості рівня життя людини і збільшення іiі тривалості.

Одним із елементів будь-якої технологічної схеми зазвичай $є$ реактор. Як правило вибір його конструкції обумовлений специфікою тих процесів, що протікають в ньому та продуктивністю виробництва [1].

Серед низки інших, біотехнологічна промисловість виготовляє безліч продуктів, що мають широкий спектр застосування. Через постійно зростаючий попит на таку продукцію дана галузь входить до числа найрозвинутіших галузей в плані інновацій. Високий вихід продукту, максимальний ступінь перетворення сировини та найбільша селективність процесу є основними вимогами, що забезпечуються за рахунок підбору оптимальних параметрів технологічного процесу.

Аналогічно останнім часом нанокомпозити отримали широке застосування у аерокосмічній, біомедичній галузях, у галузі електроніки та у виробництві кераміки різного призначення. У керамічному виробництві велику увагу приділяють гомогенізації та створенню оптимальних умов формування нанокомпозитів [2].
Основними факторами, що повинні постійно підтримуватися у технічному завданні на проектування реакторів, є максимальна продуктивність та інтенсивність, великий вихід кінцевого продукту, мінімальні енергетичні затрати, безпечність роботи, низька вартість експлуатації, технічного обслуговування та ремонту [3].

Метою роботи є дослідження впливу геометрії лопатей перемішуючого пристрою та їх розташування у просторі на швидкість та напрями потоків у реакторі.

\section{Матеріали та методи дослідження}

Весь спектр способів оформлення процесів, що протікають в промислових реакторах $з$ метою отримання продуктів реакції, базується на організації штучно створених умов середовища в апараті.

Апарат з механічним перемішуючим пристроєм представляє собою найбільш вдалий варіант конструктивного оформлення хімічних та біотехнологічних процесів, в яких процес перемішування направлений на гомогенізацію середовища та забезпечення розвиненої міжфазної поверхні.

Для конструювання такої технологічної апаратури потрібно враховувати тип системи, в якій проходять процеси. Зазвичай середовище реактора являє собою складну рідку гетерогенну систему в якій 
присутні, як правило, 3 - 4 фази, що розділені міжфазною поверхнею:

- рідка фаза - вода у якій розчинені або дисперговані певні компоненти реакційної маси;

- квазітверда фаза - частки різних агентів;

- газова фаза - представлена повітрям, або іншим газом, що системно подають у реактор;

- тверда фаза - фаза, що знаходиться в процесі розчинення та представлена конгломератом твердих частинок [3 - 4].

Ключовим параметром, що переслідують усі підприємства, є налагодження продуктивного виробництва.

Суттєвою складовою процесу культивування або гомогенізації є забезпечення повного та однорідного розчинення компонентів вихідного середовища.

Невід'ємним компонентом масообмінних процесів $\epsilon$ процес перемішування, від інтенсивності якого залежить гомогенність середовища та швидкість транспорту складових речовин в апараті. Іншим невід'ємним компонентом є масштаб турбулентних пульсацій. Він суттєво впливає на зміну поверхні масопередачі. За допомогою теорії турбулентності можна оцінити масштаб та інтенсивність турбулентності $[5,6]$.

Одним 3 можливих напрямів створення ефективних конструкцій 3 керованими гідродинамічними параметрами є розробка ефективної геометрії лопатей та їх оптимальне розташування у об'ємі апарата, що забезпечить більшу інтенсивність процесу перемішування та унеможливить виникнення застійних зон. Суттєвою особливістю конструювання типового обладнання $є$ врахування особливостей фізико-хімічних та/або біотехнологічних процесів, що протікають в середині апаратів. Це практично унеможливлює створення універсальних реакторів.

Конструкції перемішуючих пристроїв можна умовно розділити на два види: швидкохідні та тихохідні.

До швидкохідних мішалок відносять пропелерні та турбінні мішалки різних типів, а також спеціальні види мішалок, наприклад, дискові та лопатеві. Ці мішалки, залежно від форми лопатей та способу їх встановлення, можуть створювати радіальні, осьові та радіально-осьові потоки рідини.

До тихохідних мішалок відносять якірні та рамні мішалки. Вони створюють головним чином радіальний потік рідини. Ці мішалки використовуються для перемішування в'язких та важких рідин, вони інтенсифікують тепломасообмінні процеси та перешкоджають випадання осаду на стінках та дні апарата $[7-8]$.

Досвід експлуатації рамних мішалок підтверджує перспективність таких перемішуючих пристроїв. Але в апаратах великих об'ємів вони не забезпечують достатньої ефективності перемішування по їхній висоті, що може бути причиною утворення застійних зон та зниження інтенсивності вищезазначених процесів.

Претендуючи на можливість вдосконалення конструкції рамної мішалки запропоновано один із можливих варіантів доопрацювання вже існуючої конструкції, по парно розташувавши проміжні лопаті, що нахилені відносно вертикальної та горизонтальної площини. Дане технічне рішення дозволить збільшити інтенсивність перемішування за рахунок створення додаткових вертикальних потоків рідини.

Сформована концепція потребує досліджень гідродинаміки, в тому числі аналізу полів швидкості та напрямків потоків.

Як правило дослідження гідродинаміки в апаратах 3 механічними перемішуючими пристроями має за свою мету визначення базової залежності у вигляді критеріального рівняння Ейлера

$$
\mathrm{Eu}=f\left(\mathrm{Fr}, \mathrm{Re}, \Gamma_{1}, \Gamma_{2}, \ldots\right) .
$$

Отримана інформація про тип мішалки, при існуючих параметрах середовища, в подальшому використовується для розрахунку інтенсивності процесів масопередачі.

Головним елементом дослідження гідродинаміки є визначення характеру руху рідини та аналіз іiі поля швидкостей [9 - 10].

Для даної роботи дослідження було проведене в універсальній програмній системі кінцево-елементного аналізу ANSYS. Комп'ютерне моделювання використовується для аналізу складних систем та процесів на основі комп'ютерної моделі. Завдяки сучасному програмному забезпеченню можна легко створити тривимірну модель деталі та провести числові дослідження.

Моделювання проведено з метою аналізу впливу геометрії перемішуючого пристрою на швидкість i напрям потоків рідини в апараті. Для проведення дослідження були побудовані 3D-моделі двох різних типів геометрії перемішуючого пристрою (рис. 1).

В основу запропонованої конструкції перемішуючого пристрою поставлена задача інтенсифікації процесу перемішування за рахунок підвищення ефективності перемішування по висоті апарата. Поставлена задача розв'язується тим, що в перемішуючому пристрої, який складається 3 валу та лопатей згідно із запропонованою конструкцією, лопаті встановлюються 3 кроком по вісі валу під кутом до вертикальної та горизонтальної площин із нахилом одна до одної, лопаті ліворуч і праворуч від валу мають протилежний нахил, а кінці лопатей прикріплені до вертикальних та горизонтальних пластин. 
Таке розміщення лопатей забезпечує більш інтенсивне та рівномірне перемішування як по висоті так і по перерізу всього апарата.

Для математичного моделювання процесу перемішування, що представлений у вигляді потоків рідини, що створюються за допомогою рамного перемішуючого пристрою, спочатку необхідно створити 3D модель об'єкта (рис. 2). Для того щоб коректно змоделювати процес перемішування, необхідно ви-

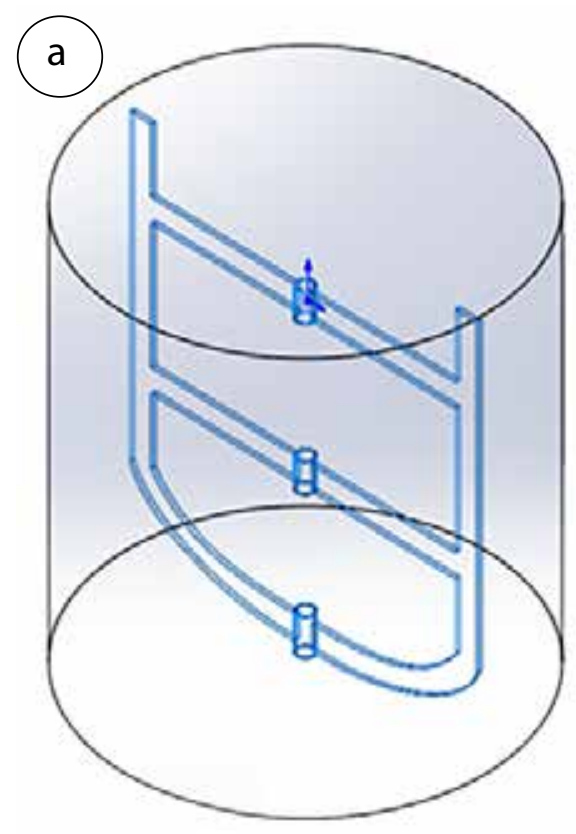

значити два об'єми: під номером один визначений об'єм рідини, що обертається навколо поздовжньої осі симетрії апарата, позиція 2 визначена як стаціонарна.

Обидва об'єми задаються як рідина і розбиваються на сукупність кінцевих елементів за допомогою модуля Mesh. Взаємодія поверхонь об’єктів, що контактують, визначена як «frozen», це означає, що швидкість на поверхні одного елемента за величи-

Рис. 1. Геометрія конструкції перемішуючого пристрою: а - стандартна; б - вдосконалена
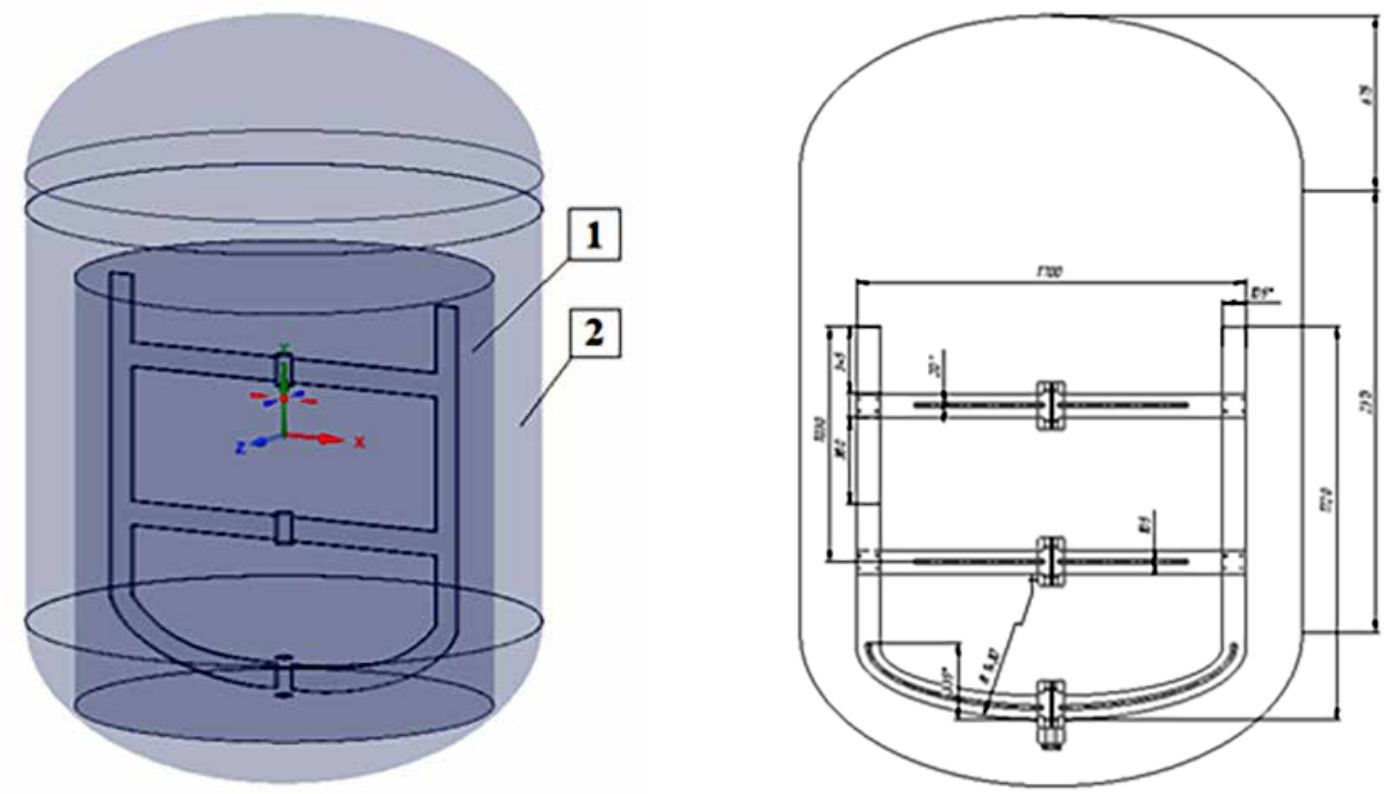

Рис. 2. 3D модель та розміри об’єкта зі стандартною конструкцією рамної мішалки 
ною і напрямом в кожній точці дорівнює швидкості на поверхні іншого. Зовнішня поверхня стаціонарного об'єму задається як нерухома. Також була задана кутова швидкість обертання $n$ рухомого об'єму рідкої фази, що становить 60 об./хв. Були зазначені початкові умови проведення розрахунків (розв'язання моделі), що надає можливість оцінити поля швидкості рідини при роботі перемішуючого пристрою.

В об'ємі реактора знаходяться дві речовини, що в початковий момент часу мають температуру $25^{\circ} \mathrm{C}$ та нульову швидкість:

- «Air» - речовина із бібліотеки, що визначається фізико-хімічними параметрами повітря при температурі за відповідної температури;

- «Liquid»-створена і добавлена власноруч умовна речовина.

Речовина «Liquid» має наступні теплофізичні параметри: густина $\rho=1104$ кг/м ${ }^{3}$, питома теплоємність $\mathrm{c}_{\mathrm{p}}=2253$ Дж/(кг·К), коефіцієнт динамічної в'язкості $v=0,7212 \cdot 10^{-3}$ Па $\cdot$, коефіцієнт теплопровідності $\lambda=0,52 \mathrm{BT} /\left(\mathrm{M}^{\circ} \mathrm{K}\right)$. Температура стінки 3 боку сорочки становить $130{ }^{\circ} \mathrm{C}$. Також зазначимо, що тиск в апараті дорівнює атмосферному.

\section{Результати та їх обговорення}

На рис. 3 представлені вектори швидкості потоків рідини, що виникають під дією обертового руху стандартної конструкції мішалки. Модель показує, що при використанні даної мішалки виникають переважно радіальні потоки рідини. 3 рис. 3 видно, що в об'ємі апарата виникають застійні зони, що розташовані поміж горизонтальними лопатями. Це зумовлено недостатньою інтенсивністю перемішування рідини по висоті апарата. Максимальна локальна швидкість потоків рідини при використанні даної мішалки становить 2,49 м/с.

Була запропонована конструкція рамного перемішуючого пристрою, що буде інтенсифікувати перемішування по висоті апарата та перешкоджати утворенню застійних зон. Таким технічним рішенням може бути конструкція з декількома додатковими лопатями, які встановлені під певним кутом.

Математичне моделювання процесу перемішування буде відрізнятися лише геометрією перемішуючого пристрою (рис. 4). Усі інші припущення, що викладені вище, залишаються незмінними.

На рис. 5 представлені вектори швидкості потоків рідини, що виникають під дією обертового руху мішалки. Модель показує, що потоки рідини, в цій ситуації, мають інший характер, ніж у випадку зі стандартною конструкцією перемішуючого пристрою. 3 рис. 5 видно, що в порівнянні зі стандартною конструкцією рамної мішалки, в модернізованій конструкції вже значно краще виражені осьові

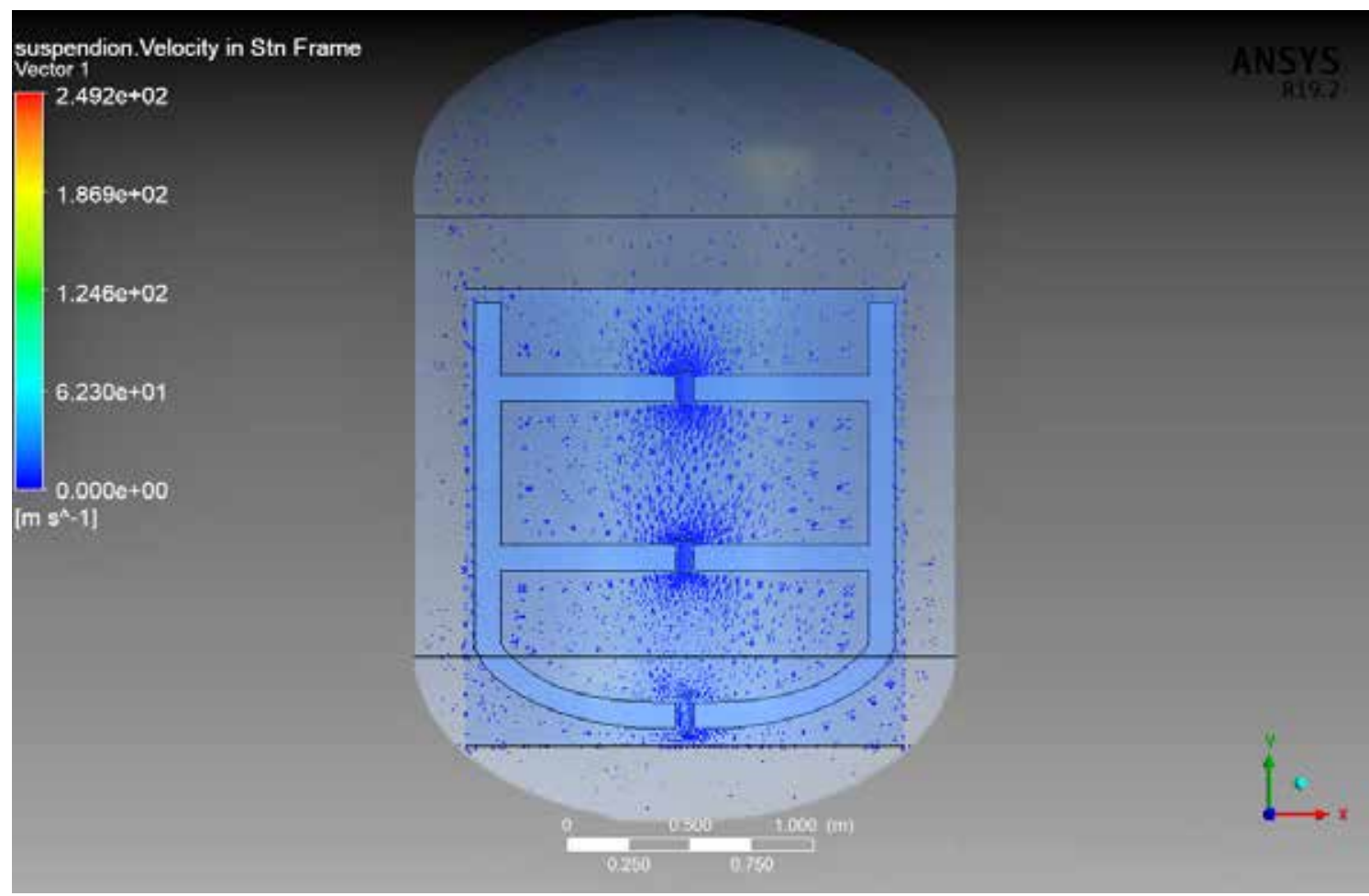

Рис. 3. Вектори швидкості потоків рідини $(n=60$ об./хв.) 
потоки рідини, що утворились за рахунок завихрення рідини навколо похилих лопатей. Максимальна локальна швидкість потоків рідини при використанні такої мішалки становить 2,45 м/с. Дана конструкція мішалки збільшує інтенсивність перемішування по висоті апарата та зменшує ризики виникнення застійних зон.



Також був проведений аналіз впливу перемішування на інтенсивність нагрівання середовища в апараті з боку стінок сорочки.

Розглянемо зміну температур в конкретній області апарата для двох конструкцій перемішуючого пристрою. Точка, в якій розглядалась зміна температур, зображена на рис. 6. у вигляді хрестика.

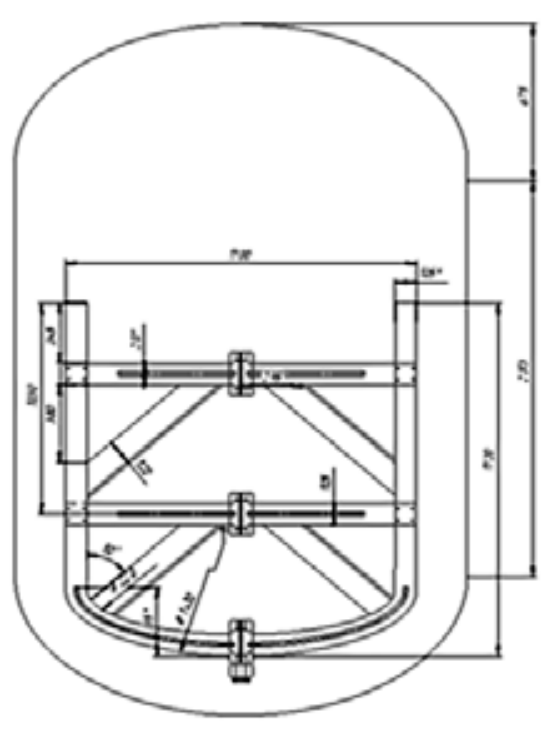

Рис. 4. 3D модель об’єкта з модернізованою конструкцією рамної мішалки

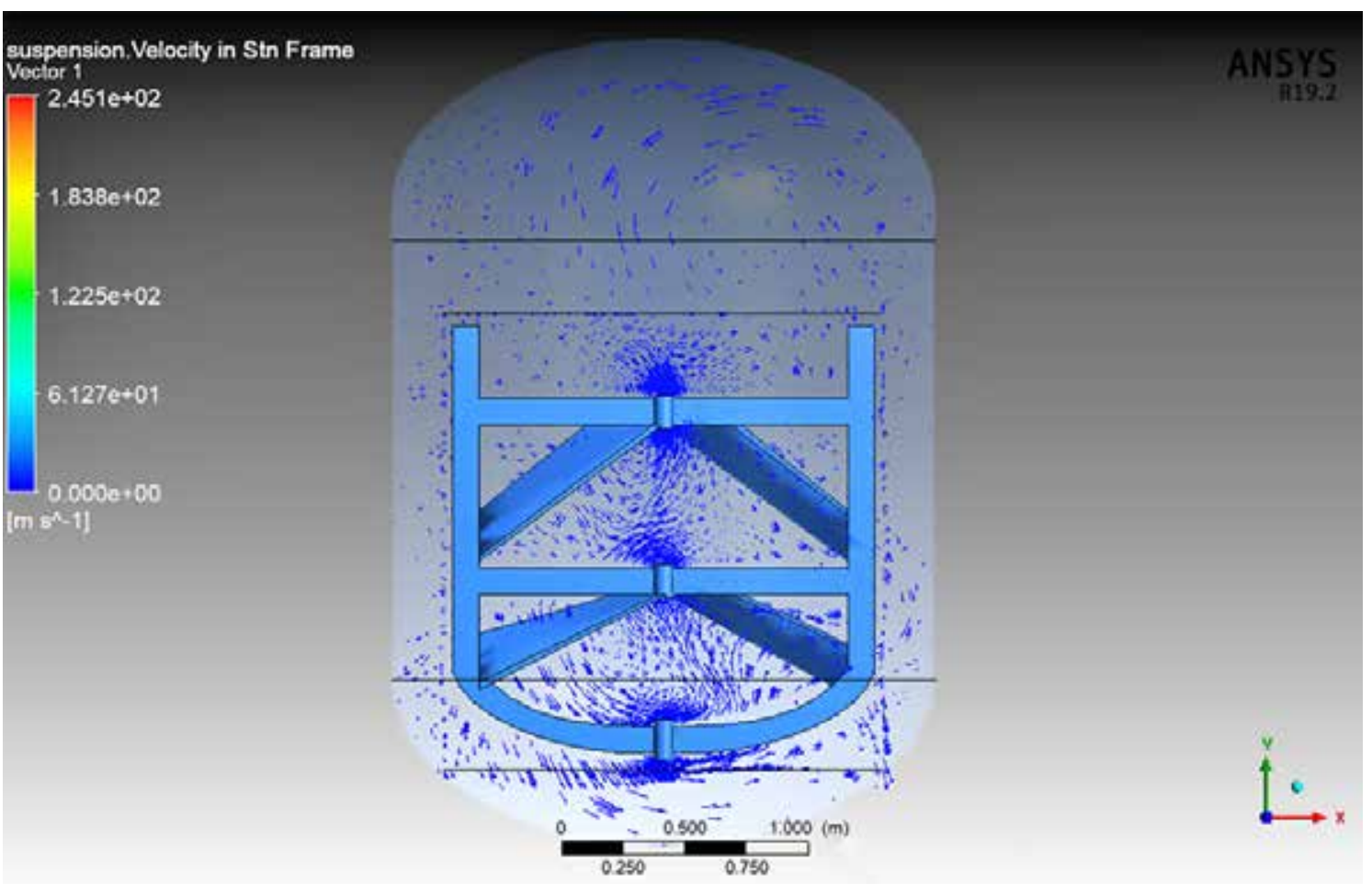

Рис. 5. Вектори швидкості потоків рідини $(n=60$ об./хв.) 


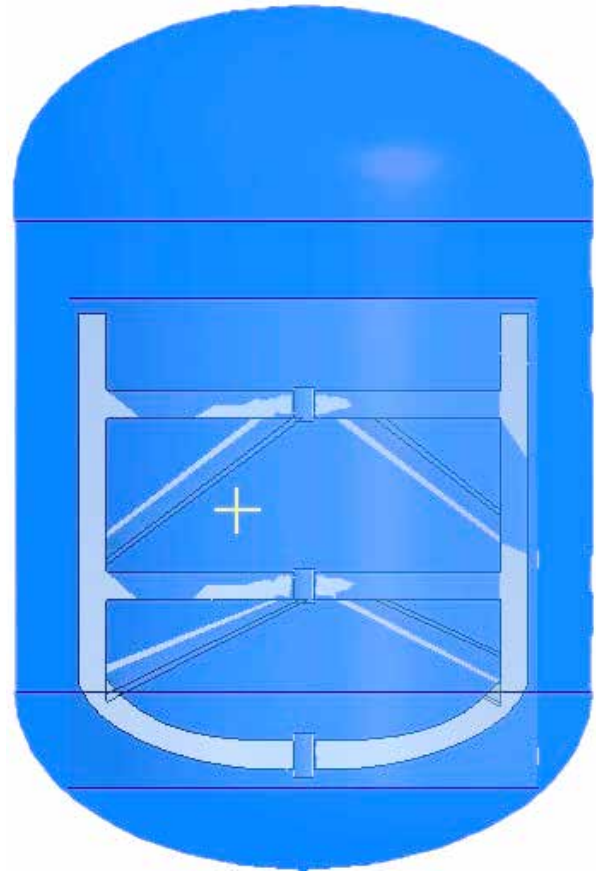

Рис. 6. Точка, в якій розглядалася зміна температур

Графіки зміни температур, із використанням стандартної та модернізованої конструкцій, зображені на рис. 7.

3 графіків видно, що у випадку з модернізованою конструкцією температура в пристінній області за десять секунд змінювалася більш стрімко та стрибкоподібно. Це вказує на те, що рідина інтенсивніше циркулювала в пристінній області, тим самим не даючи утворенню локального перегріву.

Середня різниця температур із використанням стандартної та модернізованої конструкції мішалки становить $0,2{ }^{\circ} \mathrm{C}$. Це свідчить про те, що у випадку модернізованої конструкції мішалки теплообмін відбувається більш інтенсивно у порівнянні зі стандартною конструкцією мішалки.

\section{Висновки}

Стандартна конструкція рамного перемішуючого пристрою не забезпечує достатньо ефективного перемішування по висоті апарата, що не дозволяє забезпечувати сталість гідродинамічних параметрів в апараті, і тим самим необхідну інтенсивність масопередачі. Для усунення вищезазначених недоліків стандартної конструкції процес перемішування здійснюється модернізованою конструкцією рамної мішалки, що відрізняється кількістю лопатей та їх розташуванням у просторі.

Ця конструкція мішалки дозволяє рівномірно гомогенізувати середовище та створити додаткові зони турбулізації рідини, що забезпечить інтенсифікацію масопередачі, і як наслідок підвищить ефективність роботи реактора.

Математичне моделювання процесу перемішування дозволило отримати адекватне зображення потоків рідини в ANSYS. Для двох різних конструкцій були визначені розподіли температур та швидкості і напрямки руху рідини.
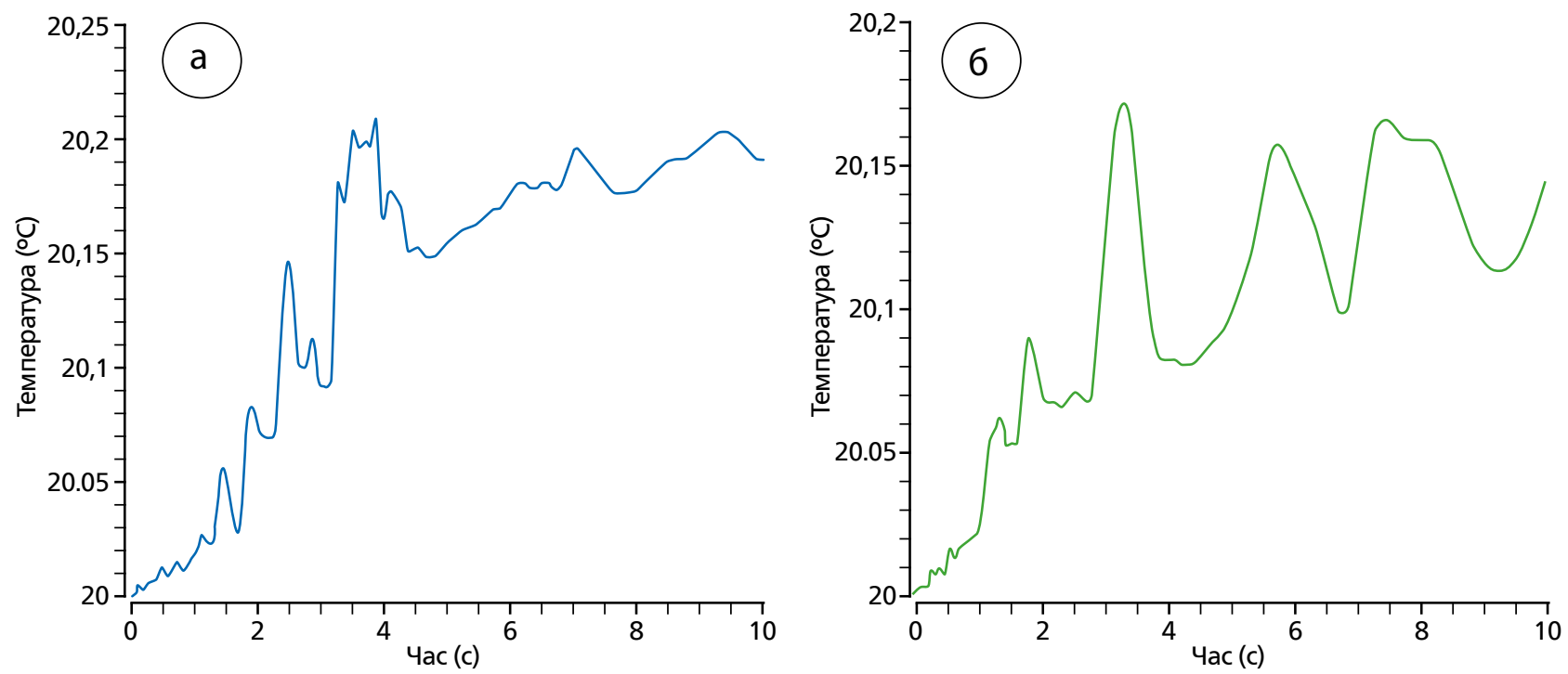

Рис. 7. Графіки розподілу температури в пристінній області реактора: a - при використанні стандартної конструкції перемішуючого пристрою; б - при використанні модернізованої конструкції перемішуючого пристрою. 
При використанні модернізованої конструкції перемішуючого пристрою виникають додаткові осьові та радіальні потоки рідини. Це забезпечує інтенсивніше перемішування у порівнянні зі стандартною рамною мішалкою.

Дана конструкція перемішуючого пристрою може бути використана у виробництві кераміки. Вона забезпечить інтенсивніший масообмін, гомогенізацію середовища та кращі умови для утворення нанокомпозитів в керамічній промисловості тощо.

\section{References}

1. Kafarov, V.V. Modeling of biochemical reactors [Text] / V.V. Kafarov, A.Yu. Vinarov, L.S. Gordeev. M.: Forest industry, 1979. -344 p.

2. Jakubine, M.B., Ashrafi, B., Zhang, Yu., Martinez-Rubi, Y., Ch, T., Kingston, A., Simard, B. Single-walled carbon nanotube - epoxy composites for structural and conductive aerospace adhesives. Composites Part B: Engineering. - 2015. - 69. - P. 87 - 93. https://doi. org/10.1016/j.compositesb.2014.09.022.

3. Vasiltsov, E.A., Ushakov, V.G. Apparatus for mixing liquid media [Reference manual] - 1978. - P. 270.

4. Kazenin, D.A. Hydrodynamics, mass transfer and energy consumption in hollow devices with a stirrer [Text] / D.A. Kazenin, I.V. Chepura, I.A. Petrov, V.A. Zhavoronkov // Teoreticheskie osnovy khim. technology. - 2008. - V. 42, № 2. - P. 128 - 134.

5. Sergeev, V.A. Cell cultures in veterinary medicine and biotechnology [Text] / V.A. Sergeev, Yu.A. Sobko. Kiev: Harvest. $-1990 .-152$ p.

6. Kolmogorov, A.N. Local structure of turbulence in an incompressible viscous fluid at very large Reynolds numbers [Text] / A.N. Kolmogorov // Dokl. USSR Academy of Sciences. - 1941. - V. 30, № 4. P. 299 - 303.

7. Strenk, F. Mixing and apparatus with stirrers. 1975. - P. 370.

8. Barabash, V.M. Problems and tendencies of development of the theory and practice of mixing of liquid media [Text] / V.M. Barabash, V.I. Begichev, M.A. Belevitskaya, N.N. Smirnov // Teoreticheskie osnovy khim. technology. - 2007. - V. 41, № 2. - P. 140 - 147.

9. Timkin, L.S. Measurement of the local sliding velocity of bubbles in an ascending pseudoturbulent flow [Text] / L.S. Timkin // Thermophysics and Aeromechanics. - 2000. - V. 7, № 1. - P. 101 - 114.

10. Smolyakov, A.V. Measurement of turbulent pulsations [Text] / A.V. Smolyakov, V.M. Tkachenko. - Leningrad: Energiya. - 1980. - 264 p. 